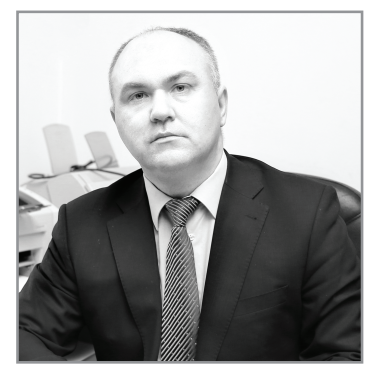

Фальковський А. О.*

к. ю. н., доцент кафедри державознавства і права

Одеського регіонального інституту державного управління Національної академії державного управління при Президентові України (м. Одеса, Україна)

ORCID: https://orcid.org/0000-0002-2255-4392

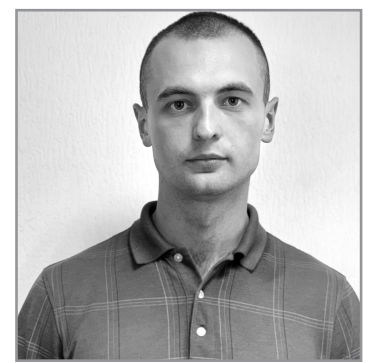

\author{
Єршов Д. А.** \\ магістр \\ Одеського регіонального інституту \\ державного управління \\ Національної академії державного \\ управління при Президентові України \\ (м. Одеса, Україна) \\ ORCID: https://orcid.org/0000-0001-7351-115X
}

*Andrii Falkovskyi, PhD in Law, an Associate Professor, Department of State Studies and Law of Odessa Regional Institute for Public Administration of the National Academy for Public Administration under the President of Ukraine (22, Henuezka St., Odessa, Ukraine).

**Denys Yershov, Magister in Law of Odessa Regional Institute for Public Administration of the National Academy for Public Administration under the President of Ukraine (22, Henuezka St., Odessa, Ukraine).

МИТНИЙ ПОСТ-АУДИТ ЯК ІНСТРУМЕНТ ПРИШВИДШЕННЯ МІЖНАРОДНОГО ТОВАРООБІГУ ТА ПЕРЕХОДУ ДО ЯКІСНО НОВОЇ КОНЦЕПЦІЇ ПАРТНЕРСЬКИХ ВІДНОСИН “МИТНИЦЯ - СУБ'СКТИ ЗЕД” 


\title{
CUSTOMS POST-AUDIT AS AN INSTRUMENT OF INCREASING INTERNATIONAL TRADE AND APPROACH TO NEW CONCEPT OF PARTNERSHIP RELATIONS "CUSTOMS - COMPANY ENGAGED IN FOREIGN TRADE"
}

\begin{abstract}
The article is devoted to the research of the legal bases of customs post-audit, the state of its development position and the problematic issues in the domestic legal field that reduce its effectiveness. Customs control in developed democratic countries is one of the main forms of customs control applied by the customs authorities in the course of customs control. The essence of this phenomenon is that the basic customs procedures, which according to the legislation of the respective country must be carried out for goods moving across the border (import, export), are not applicable at the point of entry at the direct movement of goods or at the customs office of destination / departure, but upon completion of customs clearance and release for free circulation. Appropriate activity allows to conduct financial analysis of the company on the basis of accounting and tax reporting, and to obtain the most informative indicators that will give an objective and accurate picture of the financial condition of the organization, its profits and losses, changes in the structure of assets and liabilities, in the accounts with debtors and creditors on the basis of which it is possible to evaluate the ability of an organization to function continuously and fulfill its obligations regarding customs payments, ransom and penalties. The article identifies and structures the main problematic issues that hamper the functioning of the customs post-audit in Ukraine. On the basis of the analysis of international legislation on customs issues, it is determined that the relevant institute is an integral part of the customs system not only of Ukraine, but of other countries as well, in the context of globalization, and in particular of Eurointegration processes. A breakthrough new approach to understanding the essence of this phenomenon in the light of new concept of partnership relations "customs - company engaged in foreign trade" is proposed. A conceptually new paradigm of understanding of this institute has been proposed and substantiated, what allows, with available or even smaller resources, to achieve better results in the work and to ensure the fulfillment of the tasks assigned to the customs service.
\end{abstract}

The key words: customs control, customs post-audit, verification, conscientious trader, foreign economic activity, legal bases of customs post-audit.

Відповідно до стратегічного курсу України до європейської інтеграції з поступовим наближенням їі митного законодавства до міжнародних норм, правил та стандартів, перед митною службою постають нові виклики. Приєднання України до Конвенції про спрощення і гар- 
монізацію митних процедур від 18.05.1973 р. (далі - Кіотська конвенція) та прийняття 24.06.2005 р. Рамкових стандартів із забезпечення безпеки та спрощення процедур міжнародної торгівлі поставило перед митною службою України комплекс нових завдань, а особливо щодо адаптації вітчизняного митного законодавства, у т.ч. й щодо здійснення митного аудиту, до європейських стандартів. Пост-аудит займає важливе місце при застосуванні системи управління ризиками у державній митній справі та $є$ головним елементом подальшого підвищення ефективності діяльності митних органів. Саме розробка ефективної служби пост-митного контролю та аудиту на теперішній час дозволяє митній службі реалізовувати покладені на неї завдання: виконання та контроль за додержанням законодавства України у сфері державної митної справи, захист економічних інтересів України, здійснення митного контролю та митного оформлення товарів і транспортних засобів, що переміщуються через митний кордон України, вдосконалення форм і методів їх здійснення тощо. Процедури, пов'язані з аудитом, є ефективним засобом для здійснення митного контролю. Виходячи 3 цього постає питання прозорості митного постаудиту в Україні, а також ефективності його здійснення.

Питанням впливу митної політики держави на особливості проведення митного контролю присвятили свої роботи такі вітчизняні та зарубіжні науковці, як О. О. Берзан, О. М. Вакульчик, О. А. Гончарук, Є. В. Додін, Ю. В. Дубко, В. Ю. Єдинак, Т. С. Єдинак, О. Книшек, О. О. Панкратьєва, П. В. Пашко, Л. М. Пісьмаченко, Н. А. Томчук, В. Ю. Фабіянська, А. В. Хомутенко, С. П. Цибулько тощо. Зазвичай дослідженню підлягають питання нормативного врегулювання та проблеми організаційного характеру, при цьому, у вітчизняній науці практично відсутні фундаментальні дослідження відповідної проблематики, що обумовлює необхідність подальших розробок.

Актуальність теми не викликає сумнівів та обгрунтовується євроінтеграційними та глобалізаційними процесами, що наразі відбуваються в Україні та вимагають суттєвих змін в існуючих підходах до здійснення митного контролю. Значне збільшення транскордонного руху капіталів стало викликом для багатьох держав у питаннях забезпечення 3 одного боку ефективного функціонування економіки, а з іншого забезпечення безпеки економічної системи держави та громадян.

Упровадження до національного митного законодавства інституту митного пост-аудиту дозволяє пришвидшити доступ товарів на митну 
територію країни шляхом спрощення митних формальностей. Однак не менш важливим є отримання повної та об'єктивної інформації про зовнішньоекономічну операцію для здійснення ефективного митного контролю.

Для реалізації політики спрощення митних формальностей при переміщенні товарів через митний кордон необхідним є обмеження кількості документів та відомостей, які мають при цьому подаватися. 3 одного боку, за таких умов простежується певна позитивна тенденція - пришвидшення доступу товарів на митну територію України, збільшення товарообігу та, відповідно, надходжень до державного бюджету країни. Водночас це унеможливлює отримання повної та об'єктивної інформації щодо комерційних транзакцій, що спричиняє появу ризиків недостовірного декларування товарів окремими суб'єктами зовнішньоекономічної діяльності. Наслідком цього є можливе одержання ними необ' єктивних фінансових переваг над сумлінними учасниками зовнішньої торгівлі, а також недоотримання бюджетами відповідних рівнів коштів у повному обсязі. Зменшення ризиків порушення вимог митного законодавства залежить від надійності митного контролю та реалізації його форм на засадах недискримінації і транспарентності, ефективності та результативності, що є демократичними і альтернативним підгрунтям для зниження ступеня жорсткості контрольних заходів. Це зумовило впровадження у митну практику такої дієвої форми контролю, як митний пост- аудит.

Одразу варто звернути увагу на відсутність єдиної дефініції, яка б окреслювала відповідну процедуру. Так, в англійській мові зустрічаються такі терміни, як "post customs audit", "post customs control", "post clearance control”, "post clearance audit", “post entry audit”. Незважаючи на різноманітність, їх суть можна підвести під спільний знаменник та говорити, що означають вони те саме - зведення до мінімуму митних формальностей під час, власне, транскордонного переміщення та перенесення контролю на момент - після випуску товарів у вільний обіг.

Більш цікавою та такою, що потребує певного врегулювання, $є$ питання категоріального апарату у відношенні даного питання саме У внутрішньому законодавстві. У Митному кодексі України (далі МКУ), законодавче визначення поняття "митний пост-аудит" відсутнє. У ст. 345 МКУ визначено, що документальна перевірка - це сукупність заходів, за допомогою яких органи доходів і зборів переконуються у правильності заповнення митних декларацій, деклара- 
цій митної вартості та у достовірності зазначених у них даних, законності ввезення (пересилання) товарів на митну територію України або на територію вільної митної зони, вивезення (пересилання) товарів за межі митної території України або за межі території вільної митної зони, а також своєчасності, достовірності, повноти нарахування та сплати митних платежів. Законом України "Про аудит фінансової звітності та аудиторську діяльність" аудит фінансової звітності визначено як аудиторську послугу з перевірки даних бухгалтерського обліку i показників фінансової звітності та/або консолідованої фінансової звітності юридичної особи або представництва іноземного суб'єкта господарювання, або іншого суб'єкта, який подає фінансову звітність та консолідовану фінансову звітність групи, з метою висловлення незалежної думки аудитора про іiї відповідність в усіх суттєвих аспектах вимогам національних положень (стандартів) бухгалтерського обліку, міжнародних стандартів фінансової звітності або іншим вимогам; аудиторську діяльність як незалежну професійну діяльність аудиторів та суб'єктів аудиторської діяльності, зареєстрованих у Реєстрі аудиторів та суб'єктів аудиторської діяльності, з надання аудиторських послуг. Згідно з розділом 2 Додатку II Міжнародної конвенції про спрощення і гармонізацію митних процедур, “контроль на основі методів аудиту" - це сукупність заходів, за допомогою яких митна служба переконується у правильності заповнення декларацій на товари та достовірності зазначених у них даних, перевіряючи наявні у причетних до декларування осіб відповідні книги обліку рахунків, документи, облікову документацію та комерційну інформацію.

На початку 2016 р. набув чинності Розділ IV “Торгівля і питання, пов'язані 3 торгівлею" Угоди про асоціацію між Україною та Європейським Союзом, реалізація положень якого має на меті сприяння створенню поглибленої зони вільної торгівлі шляхом поступового скасування ввізних і вивізних мит. Зона вільної торгівлі між Україною та Свропейським Союзом, окрім відмови від стягнення мит та ліквідації технічних бар'єрів, передбачає співпрацю у максимально наближеному до європейських норм законодавчому полі. Результатом гармонізації вітчизняного законодавства 3 нормами ЄС має стати зменшення кількості перевірок суб'єктів господарювання, скасування вимог щодо ліцензування та сертифікації більшості видів діяльності, спрощення системи бухгалтерського обліку, скорочення корупції тощо. Першочергове місце в цьому процесі належить 
реалізації ефективної митної політики, зокрема, у напрямку здійснення постмитного контролю.

Основною метою впровадження митного постаудиту у контрольно-перевірочну роботу митних органів $є$ : формування прозорої митної системи, що була б адекватною сучасним тенденціям світової торгівлі, відповідала б нормам, прийнятим у розвинених країнах, та належним чином здійснювала захист законних економічних прав суб'єктів зовнішньоекономічної діяльності та держави (Вакульчик, 2013 , с. 11). Тому надання пріоритетного значення процедурам постмитного контролю дозволить скоротити час митного оформлення, полегшити процес проходження митних формальностей для сумлінних суб' єктів зовнішньоекономічної діяльності, у кінцевому рахунку усуваючи торговельні бар'єри.

Хоча 3 моменту набуття чинності новим Митним кодексом у 2012 р. розпочався якісно новий період розвитку постмитного контролю в Україні, невирішеними досі залишаються питання розробки методики проведення постмитних перевірок, включаючи документування та регламентацію роботи контролерів відповідно до різних напрямків перевірок та інші проблеми, які потребують законодавчих змін. В. П. Хомутенко та А. В. Хомутенко серед факторів негативного впливу на формування системи митного пост-аудиту виділяють наступні проблеми: правові, методологічні, організаційні, людські та інформаційні (Хомутенко, 2014, с. 112). Неможливо наблизити митне законодавство України до міжнародних норм, зокрема, до положень Кіотської конвенції у частині запровадження постмитних перевірок, якщо у вітчизняному Митному кодексі відсутнє визначення цього поняття. Тому одним із основних завдань модернізації українського митного законодавства та наближення його до вимог Європейського Союзу є доповнення Митного кодексу України необхідними базовими поняттями (Сагарьова, 2012, с. 98). Не зважаючи на те, що науковцями та практиками неодноразово висувалися пропозиції щодо закріплення терміну "митний пост-аудит" на державному рівні шляхом доповнення ст. 4 Митного кодексу України, жодних змін досі не відбулося.

До організаційних проблем, які гальмують розвиток системи постмитного контролю в Україні, слід віднести недосконалу структуру державного апарату, що регулює питання митної політики країни. 32012 р. відбулося об'єднання податкової та митної служб шляхом створення Міністерства доходів і зборів України, яке у 2014 р. було 
реорганізовано у Державну фіскальну службу України. 3 моменту затвердження Положення про Державну фіскальну службу України питання регулювання та проведення документальних перевірок перейшли до повноважень цього новоствореного центрального органу виконавчої влади. На сьогодні у структурі апарату Державної фіскальної служби України функціонує Департамент податкового та митного аудиту, до компетенції якого віднесено питання здійснення постмитного контролю. У результаті об'єднання митної та податкової служб, включно з підрозділами аудиту, митні органи були фактично позбавлені можливості проводити власний постмитний контроль. Близько 90\% усіх питань, які перевіряються під час постмитного контролю, належать до виключної компетенції митниць, базуються на відповідних фахових знаннях і потребують досвіду роботи у митній справі. Як приклад, у напрямку контролю митної вартості ефективність роботи митних органів знизилась через втрату ними низки підрозділів, які забезпечували надання підрозділам контролю митної вартості необхідної інформації та забезпечували її реалізацію, зокрема, і підрозділів постаудиту (Лікарчук, 2015, с. 1).

Найбільша кількість невирішених питань на сьогоднішній день стосується методичного забезпечення постмитних перевірок. У Митному кодексі України закріплені лише базові положення з проведення документальних перевірок, що за своєю суттю відповідають постмитному контролю. Зокрема, положення Кодексу містять інформацію щодо видів, періодичності, строків проведення перевірок, прав і обов' язків як контролюючих органів, так і суб' єктів господарювання. Необхідно враховувати, що митний режим, відповідно до якого відбувається переміщення товарів через митний кордон, зумовлює використання специфічного переліку процедур митного контролю, у т.ч. й постмитних перевірок на етапі післямитного оформлення. Відповідно до чинного законодавства, в Україні передбачено 14 митних режимів: імпорт (випуск для вільного обігу), реімпорт, експорт (остаточне вивезення), реекспорт, транзит, тимчасове ввезення, тимчасове вивезення, митний склад, вільна митна зона, безмитна торгівля, переробка на митній території, переробка за межами митної території, знищення або руйнування, відмова на користь держави (Митний кодекс України, 2012). Одним із першочергових кроків на шляху до підвищення ефективності постмитного контролю в Україні $\epsilon$ розробка окремих методик його проведення відповідно до специфіки кожного 
зазначеного митного режиму. Крім специфіки митних режимів, під час розробки методик проведення постмитного контролю необхідно прийняти до уваги статистику митних правопорушень. Серед найпоширеніших методів ухилення від сплати податків виділяють: транспортування товарів об’їними шляхами із сусідніх держав-членів СНД; перерваний транзит (вантаж, що ввозиться в Україну нібито 3 метою транзиту, з країни не виїжджає); оформлення декларації на товар під іншою назвою; давальницькі схеми: звільнення від митних зборів і платежів давальницької сировини, що дозволяє безкоштовно провозити певні товари; бартерні схеми, які застосовуються для заниження митної вартості як увезених, так і вивезених товарів; використання спеціальних економічних зон, територій пріоритетного розвитку зі спеціальним режимом інвестиційної діяльності, технопарків для нецільових операцій (Ребізант, 2003, с. 3).

Результати статистичних досліджень свідчать, що суб'єкти зовнішньоекономічної діяльності досі не позбавлені можливостей порушувати податкове та митне законодавство, використовуючи загальновідомі схеми ухилення від сплати податків і зборів. Розробка єдиних уніфікованих методик проведення постмитного контролю відповідно до визначених законодавством режимів митного оформлення, а також використання інформації про типові схеми ухилення від оподаткування сприятимуть практичній реалізації методичного забезпечення постмитного контролю та дозволять підвищити його ефективність.

Принципові відмінності полягають у тому, що митний аудит спрямований не на контроль за переміщенням товарів, а на контроль за діяльністю організацій, які мають відношення до товарів, що переміщуються через митний кордон, при цьому діяльність організацій розглядається в динаміці та оцінюється перспектива ії діяльності в майбутньому (Берзан, 2007, с. 25).

3 метою вирішення проблем, пов'язаних 3 недосконалим нормативно-правовим забезпеченням діяльності контролюючого органу, необхідно уніфікувати вітчизняне законодавство з урахуванням міжнародних норм та стандартів. Проблеми нормативно-правового регламентування митного пост-аудиту обумовлені відсутністю фундамнтальних теоретичних засад організації та функціонування цієї форми митного контролю в Україні. У цьому зв'язку необхідним $є$ теоретичне визначення та нормативне закріплення визначення поняття “митний пост-аудит”. Так, враховуючи вітчизняні правові норми та положення 
Кіотської конвенції, що ратифікована та набрала чинності в Україні 15.09.2011 р. пропонуємо під митним пост-аудитом розуміти форму митного контролю, що здійснюється посадовими особами органів, уповноважених на реалізацію митної політики країни, шляхом проведення документальних виїзних та невиїзних перевірок суб'єктів ЗЕД після факту митного оформлення товарів.

Розвитку митного пост-аудиту заважає незадовільний стан методологічної бази контрольно-перевірочної діяльності, який унеможливлює комплексне повноцінне дослідження діяльності суб'єктів ЗЕД. Отже, відсутні методичні підходи за усіма напрямками контрольно-перевірочної діяльності уповноважених суб'єктів та єдині уніфіковані технологічні схеми здійснення митного пост-аудиту за різними об'єктами контролю, не повною мірою розроблено тематику перевірок. Наприклад, на теперішній час цілковито не розроблено тематику перевірок відповідності нормам законодавства трансфертного та офшорного ціноутворення у міжнародній торгівлі (Васильєва, 2012, с. 33).

Існує об'єктивна необхідність створення нормативно-правової бази для врегулювання питань щодо методичних підходів формування ризикоорієнтованої системи відбору суб'єктів ЗЕД до митного пост-аудиту (Хомутенко, 2013, с. 169).

Зазначимо, що індикатори для автоматизованої системи селекції підконтрольних суб'єктів можна поділити на групи, ідентифікація яких здійснюється на стадіях: обліку (акредитації в єдиному реєстрі бази даних міністерства); у процесі здійснення ЗЕД. Останні можливо умовно розділити на підгрупи за стадіями виявлення: під час обробки відомостей за митними деклараціями (розрахунками); обліку платежів (податкових зобов'язань); надання їм послуг митного сервісу; здійснення контрольно-перевірочної роботи; погашення виставлених податкових повідомлень для оплати; визначення кола підконтрольних суб'єктів, які здійснюють ЗЕД, пов'язану 3 ймовірним відмиванням доходів від неї, отриманих шляхом уникнення від сплати обов'язкових платежів. Виявлення хоча б одного 3 цих індикаторів буде означати віднесення підконтрольного суб'єкта до певної категорії уваги і здійснення виконавчим органом відповідних дій, що включатимуть приділення такому суб'єкту особливої уваги та проведення відповідної роботи, а також включення його до плану-графіка проведення документальних перевірок - митного пост-аудиту (Хомутенко, 2013, с. 178). 
Крім того, проведення митного пост-аудиту повинно базуватися на праві доступу митних органів до бухгалтерських документів не лише імпортерів товарів, послуг, а й транзитних підконтрольних суб'єктів і кінцевих продавців, що дозволить повноцінно здійснювати управління ризиковими ситуаціями (Хомутенко, 2013, с. 176).

Низький рівень кваліфікації та недостатній досвід практичної роботи посадових осіб, уповноважених на здійснення документальних перевірок (митного пост-аудиту), також є перешкодою на шляху розбудови ефективно функціонуючої системи митного пост-аудиту. Зауважимо, що на теперішній час в Україні не створено умов для набуття митними аудиторами необхідного практичного досвіду та нормативно не передбачено можливості залучення фахівців-бухгалтерів й незалежних аудиторів на умовах підряду (у т.ч. у формі аутсорсингу) (Войтов, 2012, с. 211).

Підписання та ратифікація Україною 16 вересня 2014 року Угоди про асоціацію з СС також вимагає активних кроків 3 приведення адміністративної спроможності відповідних адміністративних органів у відповідність до цілей ефективного контролю та підтримки сприянню законній торгівлі. Стаття 76 Угоди закріплює домовленості сторін, що їх відповідне митне законодавство, як принципове питання, має бути стабільним та всеохоплюючим та, що положення i процедури мають бути пропорційними, прозорими, застосовуватись уніфіковано, а також повинні забезпечувати застосування сучасних митних методів, зокрема оцінки ризиків, постаудитного контролю та методу аудиту компаній для спрощення та сприяння ввезенню та випуску товарів.

У ході виконання Україною досягнутих домовленостей з митних питань доцільним було б вивчення ефективності такої форми митного контролю й підготовка методичних рекомендацій з організації та здійснення митного контролю у формі пост аудиту.

Окреслимо фундаментальні засади якісно нового підходу до поняття митного пост-аудиту. Протягом всього свого розвитку людство постійно йшло шляхом еволюції і пошуку речей, які б за менших затрат надавали більшого результату, не втрачаючи своїх якісних характеристик. У митній сфері основним завданням $є$ спрощення та пришвидшення митних процедур із збереженням, одночасно, належного рівня контролю. Митний пост-аудит i $\epsilon$ спробою та тим інструментом, який на сучасному рівні здатен 
збалансувати традиційні інтереси митниці щодо попередження шахрайства, додержання законодавства 3 питань державної митної справи та забезпечити повноту нарахування та сплати митних платежів із необхідністю спростити міжнародну торгівлю та покращити дотримання правил. Це перехід від традиційного підходу до якісно нового, заснованого на тому, що суб'єкт ЗЕД несе більшу відповідальність за дотримання встановлених правил при переміщенні товарів через митний кордон.

Недоліками та складностями традиційного підходу до митного контролю $є$ :

- суб'єкт не відчуває відповідальності за дотримання митних правил, через що це не є пріоритетом у його діяльності;

- кількість співробітників митниці завжди менша, ніж необхідно для того, щоб виявити усі помилки та напряму працювати із усіма наслідками;

- на момент проведення митного оформлення може бути відсутня уся комерційна документація, що перешкоджає належному рівню здійснення митного контролю;

- суб'єкт може продовжувати робити одні і ті ж помилки, якщо він не знає причин їх виникнення.

Спробуємо зобразити схематично традиційний підхід:

Традиційний підхід до контролю

Відповідальність трейдера

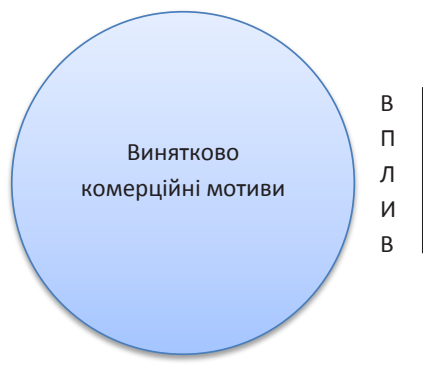

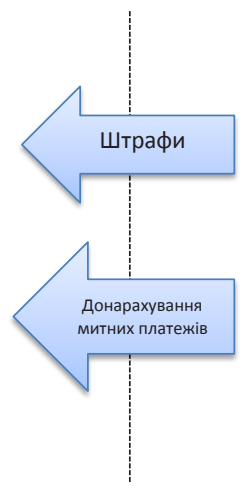

Схема 1
Відповідальність митниці

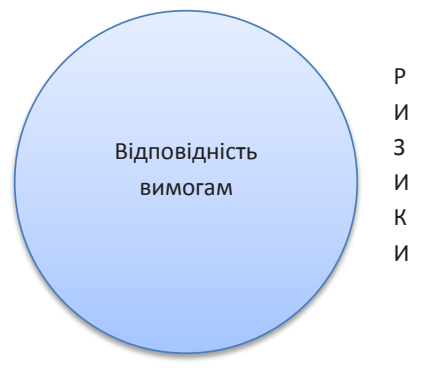


Логічно, з огляду на вищевказане, виникає питання: хто може отримати вигоду із відповідних трансформаційних процесів? По-перше, митниця. У служби завжди наявні обмежені ресурси та бюджети. Контроль після митного очищення товарів означає, що трейдер (суб'єкт ЗЕД) бере на себе відповідальність за забезпечення дотримання встановлених норм при переміщенні товарів. Таким чином, митна служба якісно та найбільш ефективно використовує свої ресурси, а також досягається більша впевненість у правильності та повноті нарахування та сплати митних платежів.

По-друге, власники бізнесу. Суб'єкти більш упевнені у ціні товарів у контексті митних витрат, що дозволяє їм краще планувати свою діяльність. Фактично, перевага для них полягає у тому, що за дотримання правил вони отримують набагато прискорені процедури митного контролю та оформлення.

По-третє, місцева влада. Надмірні заходи контролю та пов'язані $з$ цим витрати, безперечно, збільшують вартість товарів для кінцевого споживача. Митний пост-аудит забезпечує зворотній процес та надає споживчі переваги.

По-четверте, держава у цілому. Неефективні та непрозорі процедури на кордоні затримують іноземних інвесторів. Завдяки системі контролю після митного оформлення відбувається “плавне" та своєчасне, без зайвих затримок, митне оформлення товарів, що у свою чергу стимулюватиме інвестиції, які ведуть до економічного зростання держави.

3 боку митниці відбувається свого роду процес "підтримки” (аутсорсингу) у процесі якого виявляються слабкі сторони трейдера та надаються рекомендації щодо їх усунення, сам суб'єкт починає розглядати дотримання правил як невід'ємну частину своїх комерційних цілей, покращення внутрішніх систем означатиме, що помилки у майбутньому менш вірогідні, що важливо, адже відносини між суб'єктами ЗЕД та митницею можуть розвиватися як партнерські та відійти від традиційно “антагоністичного” підходу, i, безперечно, міжнародна торгівля у цілому отримає відповідні переваги.

Актуальним також є питання стосовно того, що у реаліях нашого буття неможливо стовідсотково застосувати інструмент митного пост-аудиту. Це цілковито слушна позиція, проте така ціль не переслідується. Відповідно до принципу Парето, на 20\% компаній припадає $80 \%$ бюджетних надходжень. Дані суб'єкти, як правило, є великими 
Якісно новий підхід до контролю

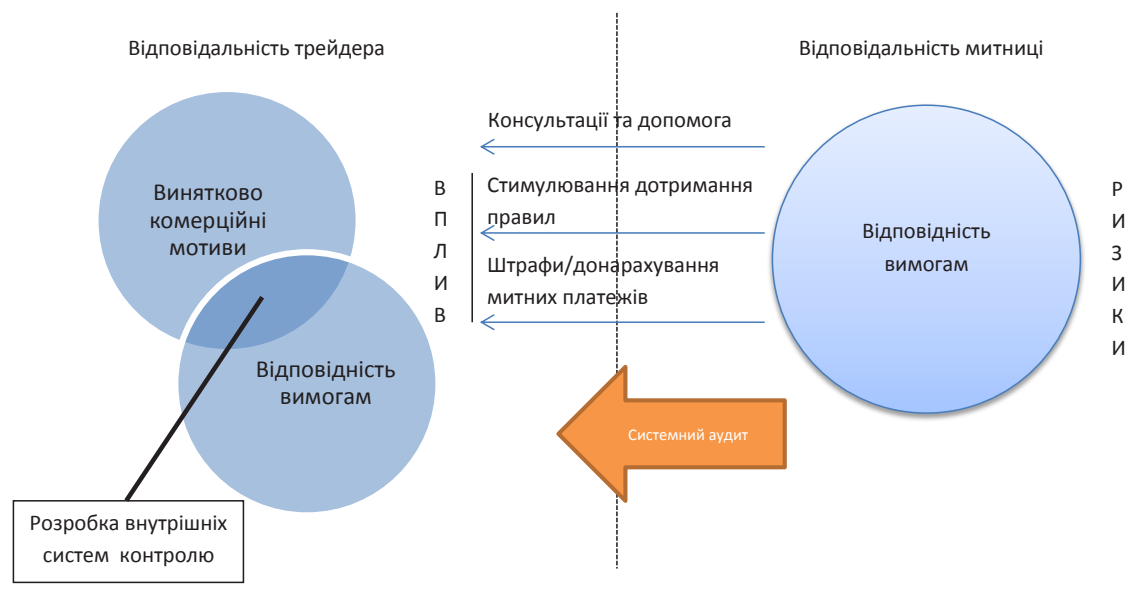

Схема 2

компаніями із високими стандартами обліку, які найбільше підходять для процедур митного пост-аудиту. Втім не лише до них може застосовуватись даний інструмент контролю, середні та малі підприємства iз належними системами обліку також придатні для пост-митного аудиту. Втім, на наше переконання, у нього є й обмеження. Деякі країни мають значний рівень неформальної торгівлі, який характеризується неналежними, або взагалі відсутністю систем бухгалтерського обліку, торгівлею на основі готівкових розрахунків та відсутністю постійного місцезнаходження підприємства, власних виробничих потужностей. Для таких суб'єктів митний пост-аудит - не найбільш практичний інструмент контролю. Проблемами тут можуть виступати пошук приміщень суб' єкта у випадку необхідності проведення перевірки за його місцезнаходженням, у таких підприємств частіше відсутні структуровані системи обліку, відсутні відповідні книги обліку чи записи тощо. Саме щодо таких підприємств, перевірка безпосередньо у момент проведення митного оформлення чи митного контролю може становити собою єдину реальну можливість проведення контролю, який повинен бути спрямований на використання методів управління ризиками. Втім митниця повинна заохочувати дотримання суб' єктами зовнішньої торгівлі митних правил, що, у свою чергу, сприятиме тому, 
що підприємства, які працюють у неформальному секторі отримають можливість формалізувати свої процедури та отримати усі переваги прозорого ведення бізнесу.

\section{Висновки}

Впровадження і розвиток постмитного контролю $є$ необхідною умовою подальшої інтеграції економіки України в європейське співтовариство. Перевірка суб'єктів зовнішньоекономічної діяльності щодо дотримання вимог митного законодавства після проходження ними митного оформлення товарів є загальновизнаним шляхом прискорення митних процедур. На рівні держави здійнюються значні кроки з удосконалення митного законодавства, його уніфікації і адаптації до європейських норм і стандартів. Однак, незважаючи на доволі ефективні законодавчо-нормативні зміни, питання постмитного контролю залишаються відкритими. Їх вирішення можливе шляхом залучення аудиторських фірм до постмитного контролю. Активну ініціативу повинні проявити як митні органи, так і Аудиторська палата України. Необхідним $\epsilon$ термінове внесення змін до законодавчих і нормативних актів, чітке визначення функції постмитного контролю, розроблення відповідного методичного забезпечення та проведення подальших наукових розробок. Це дасть змогу досягти рівня кращих світових практик щодо максимального скорочення часу, витраченого на митне оформлення, та забезпечить неухильне виконання митного законодавства суб'єктами зовнішньоекономічної діяльності. Митний пост-аудит не є самостійним процесом. Реалізація програми щодо впровадження даного інструменту у практику, окрім чіткого розуміння та підтримки керівництва на вищому рівні, потребує розробки спрощених прикордонних процедур, внесення змін до митного законодавства, розробки стратегії аудиту на основі ризиків та плану аудиту, а також нарощування потенціалу співробітництва з суб'єктами ЗЕД. Якщо із правовими передумовами все зрозуміло (нормативно закріплені вимоги щодо обліку суб'єктів, внесені зміни на законодавчому рівні щодо нових методів контролю тощо), то основною ідеєю митного стратегічного управління варто визначити те, що розробники митної політики та основних напрямків розвитку повинні бути готовими підтримати впровадження митног пост-аудиту на найвищому рівні, оскільки на початкових етапах впровадження, як митники, так і трейдери можуть скептично віднестись до моделі партнерських відносин “митниця - суб'єкти ЗЕД”. 


\section{ЛІТЕРАТУРА}

Берзан, А.А. (2007). Развитие методических основ посттаможенного контроля. Автореферат дис. канд. эконом. наук.

Вакульчик, О.М., Сдинак, Т.С., Книшек О.О. (2013). Використання досвіду СС в побудові системи законодавчого та методичного забезпечення митного постаудиту в Україні. Вісник Академії митної служби України. Сер.: “Економіка”, 2(50), 11-23.

Васильєва, В.Г., Татаренко Н.М. (2012). Сучасний стан та напрямки розвитку аудиту митної вартості товарів. Вісник Академї̈ митної служби Украӥни. Сер.: “Економіка”, 2, 33-41.

Войтов, С.Г. (2012). Митний постаудит: об'єктивна закономірність та проблеми становлення. Митна політика та актуальні проблеми економічної безпеки України на сучасному етапі: матеріали $V$ міжн. наук.-практ. конферениії молодих вчених. Дніпропетровськ, 1, 210-212.

Закон про аудит фінансової звітності та аудиторську діяльність, 2017 (Верховна Рада України). Офіційни сайт Верховної Ради Украйни. <https://zakon.rada.gov.ua/ laws/show/2258-19> (2019, серпень, 17).

Лікарчук, К. (2015). Інструмент, здатний перетворити митницю. Українська правда $<$ https:/www.pravda.com.ua/columns/2015/08/18/7078211/> (2019, серпень, 15).

Митний кодекс України, 2012 (Верховна Рада України). Відомості Верховної Ради України, 44-45, 46-47, 48, 552.

Ребізант, Р. (2003). Примусове стягнення тільки за виконавчими документами. Податкове планування, 4, 2-5.

Сагарьова, Д.О. (2012). Детермінація процедур постмитного контролю. Науковий вісник. Одеський національний економічний університет. Всеукрайнська асоціація молодих науковців. Науки: економіка, політологія, історія, 10(162), 91-100.

Угода про асоціацію між Україною, з однієї сторони, та Європейським Союзом, Європейським співтовариством з атомної енергії $і$ їхніми державами-членами, 2014. Офіційни сайт Верховної Ради Украӥни. <http://zakon4.rada.gov.ua/laws/show/984_011/ page> (2019, серпень, 15).

Хомутенко, А.В., Хомутенко, В.П. (2014). Митний пост-аудит в Україні: проблемні питання. Problems of social and economic development of business: collection of scientific articles, 2, 111-115.

Хомутенко, В.П., Запорожець, О.Ф. (2013). Система адміністрування митних платежів: теорія та практика функиіонування. Одеса.

International convention on the simplification and harmonization of customs procedures, 1973 (World Customs Organization). <https://www.ifrc.org/Docs/idrl/I273EN.pdf> (2019, August, 15).

\section{REFERENCES}

Berzan, A.A. (2007). Razvitie metodicheskih osnov posttamozhennogo kontrolja. [Development of methodological foundations of post-customs control]. Avtoreferat dis. 
kand. jekonom. nauk [The dissertation author's abstract of the candidate of economic sciences]. [in Russian].

International convention on the simplification and harmonization of customs procedures, 1973 (World Customs Organization). Retrieved from: https://www.ifrc.org/Docs/idrl/ I273EN.pdf (2019, August, 15).

Khomutenko, A.V., Khomutenko, V.P. (2014). Mytnyi post-audyt v Ukraini: problemni pytannia [Customs post-audit in Ukraine: problematic issues]. Problems of social and economic development of business, no. 2, 111-115. [in Ukrainian].

Khomutenko, V.P., Zaporozhets, O.F. (2013). Systema administruvannia mytnykh platezhiv: teoriia ta praktyka funktsionuvannia [Customs payment administration system: theory and operation practice]. Odesa. [in Ukrainian].

Likarchuk, K. (2015). Instrument, zdatnyi peretvoryty mytnytsiu [A tool that can change customs]. Ukrainska pravda [Ukrainska pravda]. Retrieved from https://www.pravda.com.ua/ columns/2015/08/18/7078211/ (2019, August, 15). [in Ukrainian].

Mytnyi kodeks Ukrainy, 2012 (Verkhovna Rada Ukrainy) [Customs Code of Ukraine, 2012 (Verkhovna Rada of Ukraine)]. Ofitsiinyi visnyk Ukrainy. [Official Bulletin of Ukraine], 44-45, 46-47, 48, 552. [in Ukrainian].

Rebizant, R. (2003). Prymusove stiahnennia tilky za vykonavchymy dokumentamy [Enforcement only by executive documents]. Podatkove planuvannia [Tax planning], no. 4, 2-5. [in Ukrainian].

Saharova, D.O. (2012). Determinatsiia protsedur postmytnoho kontroliu [Determination of post-clearance control procedures]. Naukovyi visnyk. Odeskyi natsionalnyi ekonomichnyi universytet. Vseukrainska asotsiatsiia molodykh naukovtsiv. Nauky: ekonomika, politolohiia, istoriia [Scientific Bulletin. Odessa National Economic University. AllUkrainian Association of Young Scientists. Sciences: economics, political science, history], no. 10(162), 91-100. [in Ukrainian].

Uhoda pro asotsiatsiiu mizh Ukrainoiu, z odniiei storony, ta Yevropeiskym Soiuzom, Yevropeiskym spivtovarystvom z atomnoi enerhii i yikhnimy derzhavamy-chlenamy, 2014 [Association agreement between the European Union and its Member States, of the one part, and Ukraine, of the other part]. Ofitsiynyy sayt Verkhovnoyi Rady Ukrayiny [The official website of the Verkhovna Rada of Ukraine]. Retrieved from: http://zakon4.rada.gov.ua/ laws/show/984_011/page (2019, August, 15). [in Ukrainian].

Vakulchyk O.M., Yedynak, T.S., Knyshek O.O. (2013). Vykorystannia dosvidu YeS v pobudovi systemy zakonodavchoho ta metodychnoho zabezpechennia mytnoho postaudytu v Ukraini [Using EU experience in building a system of legislative and methodological support for customs post-clearance in Ukraine]. Visnyk Akademii mytnoi sluzhby Ukrainy. Seriia "Ekonomika" [Bulletin of the Academy of Customs Service of Ukraine. Avg.: "Economics"], 2(50), 11-23. [in Ukrainian].

Vasylieva V. H., Tatarenko N.M. (2012). Suchasnyi stan ta napriamky rozvytku audytu mytnoi vartosti tovariv [The current state and directions of development of the customs value 
audit of goods]. Visnyk Akademii mytnoi sluzhby Ukrainy. Seriia "Ekonomika" [Bulletin of the Academy of Customs Service of Ukraine. Avg .: "Economics"], 2, 33-41. [in Ukrainian].

Voitov S. H. (2012). Mytnyi postaudyt: ob'iektyvna zakonomirnist ta problemy stanovlennia [Customs Postudit: Objective pattern and problems of formation]. Mytna polityka ta aktualni problemy ekonomichnoi bezpeky Ukrainy na suchasnomu etapi : materialy V mizhn. nauk.-prakt. konferentsii molodykh vchenykh. - Dnipropetrovsk. [Customs policy and current problems of economic security of Ukraine at the present stage: Proceedings of the 5th International Scientific Conference of Young Scientists. Dnipropetrovsk], 1, 210-212. [in Ukrainian].

Zakon pro audyt finansovoi zvitnosti ta audytorsku diialnist, 2017 (Verkhovna Rada Ukrayiny). [Law on Audit of Financial Reporting and Auditing 2017 (Verkhovna Rada of Ukraine)]. Vidomosti Verkhovnoi Rady Ukrainy [Statements of Verkhovna Rada of Ukraine], 9, 50. [in Ukrainian].

\section{АНОТАЦІЯ}

Фальковський А. О., Сриов Д. А. Митний пост-аудит як інструмент пришвидшення міжнародного товарообігу та переходу до якісно нової концепції партнерських відносин “митниця - суб'єкти ЗЕД”. - Стаття.

Статтю присвячено дослідженню правових основ митного пост-аудиту, стан його розвитку та проблемні питання у вітчизняному правовому полі, що знижують його ефективність. Запропоновано якісно новий підхід до розуміння суті даного явища у світлі партнерських відносин “митниця-суб'єкти ЗЕД”.

Ключові слова: митний контроль, митний пост-аудит, перевірка, добросовісний суб'єкт, зовнішньоекономічна діяльність, правові засади митного пост-аудиту.

\section{АННОТАЦИЯ}

Фальковский А. А., Ершов Д. А. Таможенный пост-аудит как инструмент ускорения международного товарооборота и перехода к качественно новой концепции партнерских отношений “таможня - субъекты ВЭД”. - Статья.

Статья посвящена исследованию правовых основ таможенного пост-аудита, состояние его развития и проблемные вопросы в отечественном правовом поле, что снижают его эффективность. Предложено качественно новый подход к пониманию сути данного явления в свете партнерских отношений “таможня-субъекты ВЭД”

Ключевые слова: таможенный контроль, таможенный пост-аудит, проверка, добросовестный субъект, внешнеэкономическая деятельность, правовые основы таможенного пост-аудита. 